\title{
Selected Journals in Library and Information Science
}

\section{Beverly P. Lynch}

his article begins a series of reviews of journals published in the field of library and information science. Although it appears under a by-line, the reviews are a project of the librarians of the University of Illinois at Chicago. Each review is signed with the initials of the librarian who prepared it. ${ }^{1}$

In a recent review of the journal literature of the field, ${ }^{2}$ Richard Johnson identifies $500-1,000$ periodicals, newsletters, and other publications in librarianship. The 1981 edition of Ulrich's International Periodicals Directory lists about 950 titles under the heading "Library and Information Services."

Older journals may be reviewed from time to time in this series in order to compare them with newer ones, or to review them again because of changes in content or style.

Access: Microcomputers in Libraries. Westfir,

Oreg.: DAC Publications. V.1, no.1

(July 1981); quarterly, \$11 per year. ISSN: 0277-9784.

The use of microcomputers in libraries is a matter of great interest to many librarians; this new publication will provide them with a useful source of information. Obviously intended for those with little computer experience, articles are short, non-technical, and non-intimidating. The first issue discusses dial-up databases and the principles underlying database management systems, publishes a field report on a microcomputer support online cata- log, interviews the creator of Lewis and Clark College's CLAS acquisitions system, and gives brief descriptions of new software and hardware products. A bargain for any library interested in microcomputer applications or increasing staff computer literacy.- LAS.

Cataloging \& Classification Quarterly. New York: Haworth Press. V.1, no.1 (Fall 1980 ), quarterly, $\$ 35$ (individuals), $\$ 45$ (institutions) per volume. ISSN: 01639374.

The "Editorial" in the first issue of Cataloging \& Classification Quarterly begins, "The appearance of any new journal in the field of librarianship requires justification." And so it does. The full contents of the first five issues of this publication and the continued appearance of articles on cataloging and classification elsewhere indicate that there is no shortage of articles. The number of articles on cataloging in most of the ALA journal publications and in almost every other library publication supports $C C Q^{\prime} s$ contention that it is filling a gap of library scholarly publishing in an area with high interest.

A look at the first few issues reveals that the articles contained here are in many cases theoretical. Nonetheless, an effort has been made to include some "how we do it good" articles and some articles that address topics related to cataloging (e.g., usefulness of archive tapes, indexes). Volume 2, numbers 1-2 (1982) contains the proceedings of the International Symposium on the Future of the Union Cata-

1. Nancy R. John, William G. Jones, Louis A. Schultheiss.

2. Richard D. Johnson, "The Journal Literature of Librarianship," in Advances in Librarianship, V.12 (New York: Academic Press, 1982), p.127-50. 
logue (University of Toronto, May 21-22, 1981). While, as is to be expected, the quality of these papers varies, this special issue makes available some materials that might be difficult to find on this important topic. It is available from Haworth as a monograph for $\$ 19.95$. It is difficult to tell yet whether issues will often follow themes; two do and three do not. As with all Haworth publications, this quarterly seems to have some difficulty meeting its publication schedule.

Except for volume 2, numbers 1-2, each issue contains book reviews. The most recent issue-volume 2, numbers 3-4 (1982)-contained twelve reviews in the space of more than thirty pages. The reviews are thorough and the choice of materials excellent, if not entirely current. The opening reviews (Michael Gorman's review of Michael Carpenter's Corporate Authorship and Carpenter's review of Gorman's Concise AACR2) demonstrate the quality of the reviewers and the kinds of materials reviewed. They also show the editor's interest in making the journal a forum for the arguing of cataloging philosophies. If the journal can sustain this standard, the book review section could outshadow the articles for some readers.

The final section, "The Cataloger's Bookshelf," contains a checklist of recently published items of interest to catalogers. In the last issue, "recently" meant between 1980 and 1982, although two 1979 imprints were included. The headline of the section indicates that selected titles will be reviewed in forthcoming issues.

A section, "News," appeared in the first issues and has either been dropped, or there has been no news to print. Until a more regular schedule is achieved, there seems little likelihood of "timely" news. The change in size between volumes one and two may also dismay library bindery units.

$C C Q$ has fared better than many $\mathrm{Ha}$ worth journals; if the initial irregularities are ironed out, $C C Q$ can have an important place in professional reading.-NRJ.

Information Services \& Use. Amsterdam: North-Holland. V.1, no.1 (March 1981), bimonthly, Dfl 158 (approx. \$73.50). ISSN: 0167-5265.

This journal describes itself as an "information and technology oriented publication with a wide scope of subject matter," including on- and off-line systems, library automation, word processing, and telecommunications. It is directed to an international audience of "librarians, information managers, designers and users of library and information systems." The issue used as the basis of this review, volume 1 , number 2 , contained five articles, three of which were papers previously read at conferences. The titles of these articles were "The Present Situation Regarding Vocal Data Acquisition" (M. J. Underwood); "The Socio-Economic Consequences and Limits of the Information Revolution" (L. J. Rankine); "Cultural and Political Traditions and Their Impact on the Transfer and Use of Scientific Information" (V. Rosenberg); "Use of the BIOSIS Computerized Data Base Taught with Audiovisual Technology" (P. M. Vaillancourt); and "International Marketing Aspects for Information Services" (A. W. Elias, a member of the threeperson editorial board). This issue's " $\mathrm{Q}$ \& $\mathrm{A}^{\prime \prime}$ column responded to the question "How do I start automating our office?" There was a section of "News, Trends, and Comments," a short conference report on the October 1981 National Reprographic Centre conference on word processors in the library, and a short book review of the Penguin Dictionary of Microprocessors. The choice of topics covers such a wide range that the reader may wonder whether there is an audience for such a journal, or whether one type of article will eventually predominate. In addition, issue number 2 was only fifty pages, so that the potential subscriber might well want to see whether the content expands before making an investment in a subscription. At this time (December 1982) no further issues have appeared.-WGJ.

Library Computer Equipment Review. Westport, Conn.: Microform Review, Inc. V.1, no.1 (Jan.-June 1979), semiannual. Price varies between $\$ 85-\$ 150$ per year, 
depending on library classification. ISSN: 0191-1295.

From the librarian's standpoint, the greatest virtues of this new publication are that it presents its material from the librarian's viewpoint, and that it does so clearly, with a minimum of jargon. Each issue is organized around a single topic, such as small business computers or turnkey circulation systems, with a state-ofthe-art report followed by reviews of six to eight products pertaining to the theme of the issue. Reports and individual reviews are illustrated, mostly with photographs. One potential problem is that everything in the two issues viewed-editorials, reports, and equipment reviews-appears to be the work of one individual. While this individual (William Saffady, of the Graduate School of Library and Information Science, Pratt Institute), is generally very well informed, this fact makes for excessive uniformity of opinion at a time when some diversity might be more useful to the reader.

The Review is expensive- $\$ 42.50$ to $\$ 75.00$ per issue - depending on the size of the acquisitions budget. It will not be of much interest to nonlibrarians. Therefore, its cost will be hard to justify unless the library supports extensive library science collections or has a working commitment to library automation.-LAS.

\section{Medical Reference Services Quarterly. New}

York: Haworth. V.1, no.1 (Spring 1982), quarterly, \$25 (individuals), \$40 (libraries, subscription agencies, other institutions). ISSN: 0276-3869.

Issue number 1 describes this new journal as a practice-oriented journal, dealing with "topics of current interest and practical value." One of the justifications for establishing this new journal is the "sense of urgency felt in medical reference work," and the need to provide extensive bibliographic services to the members of a demanding profession. Online searching will be a focus of the journal. This first issue contained four topical articles (including one bibliography on the dying patient); a column of opinion and exchange; an online update column for search ana- lysts; and a user education column publicizing "practical information on user education topics." It will include a "variety of user education material, including articles, editorial comment, notices of available programs and descriptions of successful projects." The first issue contained six book reviews ranging in length from one to three pages. Research-oriented articles are included only if they contain practical applications, analyzed and clearly presented, for the practicing medical librarian.

The significant question is whether there is a need for a new journal devoted specifically to medical reference services, there already being journals devoted to reference, to online search services, and to bibliographic instruction, all topics addressed by this title. It will be convenient for medical librarians to have these issues addressed in one title, but in spite of the overlap in coverage, it is not likely that their need to consult the existing topical titles will be obviated.-WGJ.

The Reference Librarian. New York: Haworth. Nos.1/2 (Fall/Winter 1981), 4 issues/\$40. ISSN: 0276-3877.

The Reference Librarian, edited by Bill Katz, examines a single topic in each number; its editors "seek authors who have a unique, imaginative and practical point of view about the topic under discussion. Librarians from all types and sizes of libraries will be asked to contribute, as will students and teachers and some laypersons." As with some other Haworth Press publications, each issue will be marketed as a monograph because of its devotion to a single topic. For example, the first combined issue (Nos.1/2) on "Reference Services in the $1980 \mathrm{~s}$ " contains nineteen articles in 128 pages; the third issue (Spring 1982) on "Reference Services Administration \& Management" contains sixteen articles in 125 pages and sells for \$24. Issue $1 / 2$ also contains a column entitled "In My Judgment," consisting of seventy-nine responses to a letter asking selected librarians "What does it mean to be a reference librarian and what is it going to mean in the years ahead?" The character of both 
the contributed articles and the short responses included in the column is observational, containing prescriptions for action, and written from practical experience. Of course, many of these observations are sound and even provocative, but they are only situationally valid. A journal entirely devoted to such contributions may be limited in its effectiveness. In addition, only the most dedicated reader is likely to read through all the contributions. The contributors are, however, well known for their achievements and knowledgeability, and the librarian who purchases only those issues dealing with topics of personal interest is spending resources most wisely.-WGJ.

\section{RSR: Reference Services Review. Ann Arbor,}

Mich.: Pierian Press. V.1, no.1 (Jan.l

Mar. 1973), quarterly, $\$ 39.50$.

ISSN:0090-7324.

The appointment of Nancy Jean Melin as the new editor of RSR in July 1981 was accompanied by a press release which announced that the "quarterly review is once again on a regular and timely publication schedule." At that time it added several new columns: "Indexes and Indexers," describing "the latest developments in manual and online indexing tools," and "Reference Data Bases," featuring "reviews of particular data-bases and comparative studies of their costs and value," as well as older columns, "Landmarks of Reference," "Comparative Reviews," "Government Publications," and "Reference Serials." By fall 1982 there were eleven separate columns on the topics of bibliographic instruction, comparative reviews, core collections, current surveys, government publications, indexers and indexes, landmarks of reference, reference databases, reference management, reference resources, and reference serials, each with its own editor. Issues are approximately 110 pages in length and contain the contributions of between twenty and thirty librarians and subject specialists. $R S R$ does now appear on a much more regular schedule and has clearly expanded the number of its recurring columns, evidently flourishing under the direction of its new editor.-WGJ.
Resource Sharing \& Library Networks. New York: Haworth Press. V.1, no.1 (Fall 1981), quarterly, \$35 per volume. ISSN: 0270-3173.

Two issues of Resource Sharing \& Library Networks, volume 1, number 1 and volume 1 , numbers 2-3, have appeared. A third issue, volume 1 , number 4 , has not yet been published. According to Haworth Press, the second volume will be called Network Librarian, and Glyn T. Evans, director, SUNY-OCLC, will be the new editor.NRJ.

Science \& Technology Libraries. New York: Haworth. V.1, no.1 (Fall 1980), quarterly, $\$ 42$, plus postage and handling. ISSN: 0194-262X.

Editor Ellis Mount states that this journal was established because there has not previously been any journal entirely devoted to science and technology libraries, regardless of their type of sponsorship and of the fields of science or technology with which they were involved. Each issue of this new journal is to be focused on a single theme of interest to sci-tech librarians. In addition to the topical articles, each issue is to include three special sections: (1) "Sci-Tech Online," "'a compilation of information on sci-tech databases and their online utilization"; (2) "New Reference Works in Science and Technology"; and (3) "Sci-Tech Notes," "short communications from any sci-tech librarian wishing to contribute a brief account of some new project or activity of interest to his/her colleagues." Because of the topical focus of each issue, individual issues are being marketed and sold as monographs. In spite of the editor's intent to concentrate on sci-tech libraries, the first issue with its theme of "Planning for Online Search Service in Sci-Tech Libraries," contained two articles on online searching in public libraries. Volume 2, number 2 (Winter 1981) contains a fourteen-page article by Tony Stankus on "Journals for Anatomists in Medical versus Nonmedical Biological Research Institutes," an article appropriate for the journal but outside the stated scope of the issue, "Role of Patents in Sci-Tech Libraries." The inclusion of papers outside the scope of the journal 
or the issue may serve neither author nor reader very well.

Volume 1 , number 1 contains ten articles in 132 pages (excluding columns); volume 2, number 2 contains five articles in 85 pages and sells as a monograph for $\$ 25$. In addition, the format has shrunk from 7by- 10 -inch to $5 \frac{1}{1} / 2$-by-8-inch, and the role that "Sci-Tech Notes" was to play has not materialized. Nonetheless, this journal appears to be alive and well, having now reached publication of volume 3 , number 1. Because of the publisher's intent to market this title both as a journal and its issues as monographs, greater attention should be paid matters of scope, content, format, and length in order that all consumers will receive what they intended to buy.-WGJ.

Videodisk/Teletext. Westport, Conn.: Mi- croform Review, Inc. V.1, no.1 (Winter 1981), quarterly, $\$ 52$ per volume year. ISSN: 0198-9456.

This new publication is intended for media technologists, educators, and librarians seriously interested in the uses and capabilities of videodisks and teletext. Although articles on these subjects are published in other professional journals, this is obviously an attempt to bring together material of interest to several related professions. There are wellillustrated general articles, case studies, substantial bibliographies of both general and technical articles, and news of new products and developments.

This title is a worthwhile addition to libraries with an active interest in media technology or computer-assisted instruction. - LAS. 

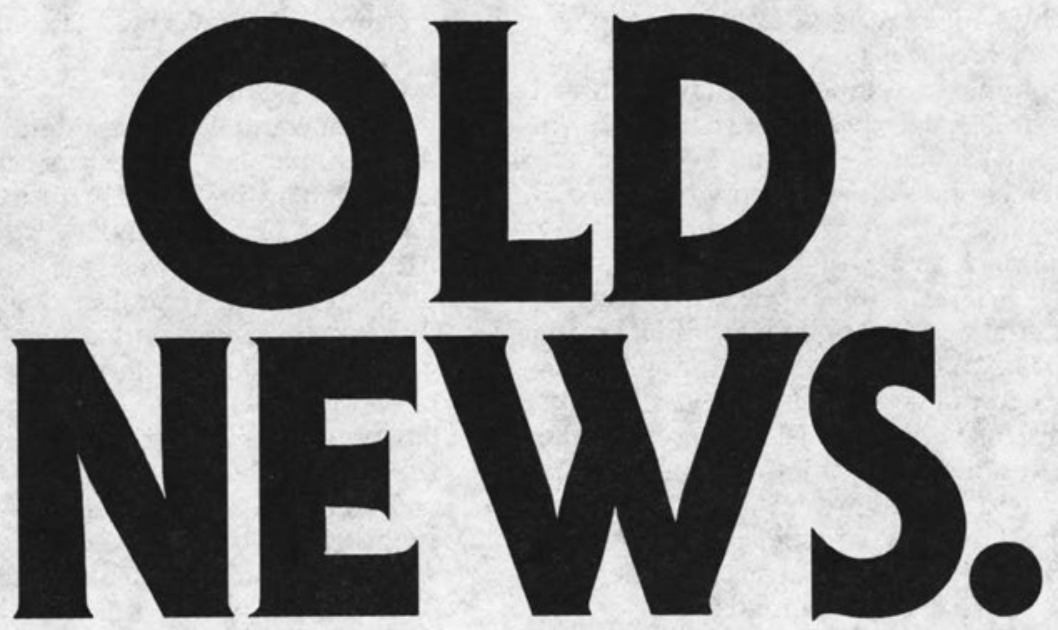

We've collected some of the great issues of our times on archival quality $35 \mathrm{~mm}$ microfilm. The news and opinion as presented by preeminent publishers worldwide, for perusal and scholarly research.

The Times of London, and its supplements, available from 1785 , or as the supplements were established by Times Newspapers of Great Britain. These newspapers share a tradition of editorial integrity and authority.

Le Monde archives dating from 1944, including its companion publications, Le Monde De L'Education and Le Monde Diplomatique, are considered to be among the most intellectual of newspapers.

The Washington Post, available from 1878, chronicles the United States' emergence to global prominence as reflected by domestic and international news.

Research Publications offers 22 other

important world newspapers in microfilm collections, including the recent addition of Neue Zürcher Zeitung and the South China Morning Post. These collections, and those of our periodicals and serials, are produced to uncompromising standards to become a permanent resource to scholarly research.

We've got the issues where the answers are found, and the indexes to provide ready access. And we offer a number of options for the acquisition of these and other microfilm collections.

If you want to know more, try Research. Research Publications, Inc.

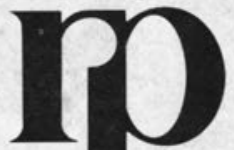

research publications, inc. 12 Lunar Drive, Woodbridge, CT 06525 (203) $397-2600$

Send me more information on your newspaper collections, in particular:
$\square$ The Times of London $\square$ The Washington Post
and supplements $\square$ The catalog on your other newspapers.
$\square$ Le Monde
Name
Title
Street
City




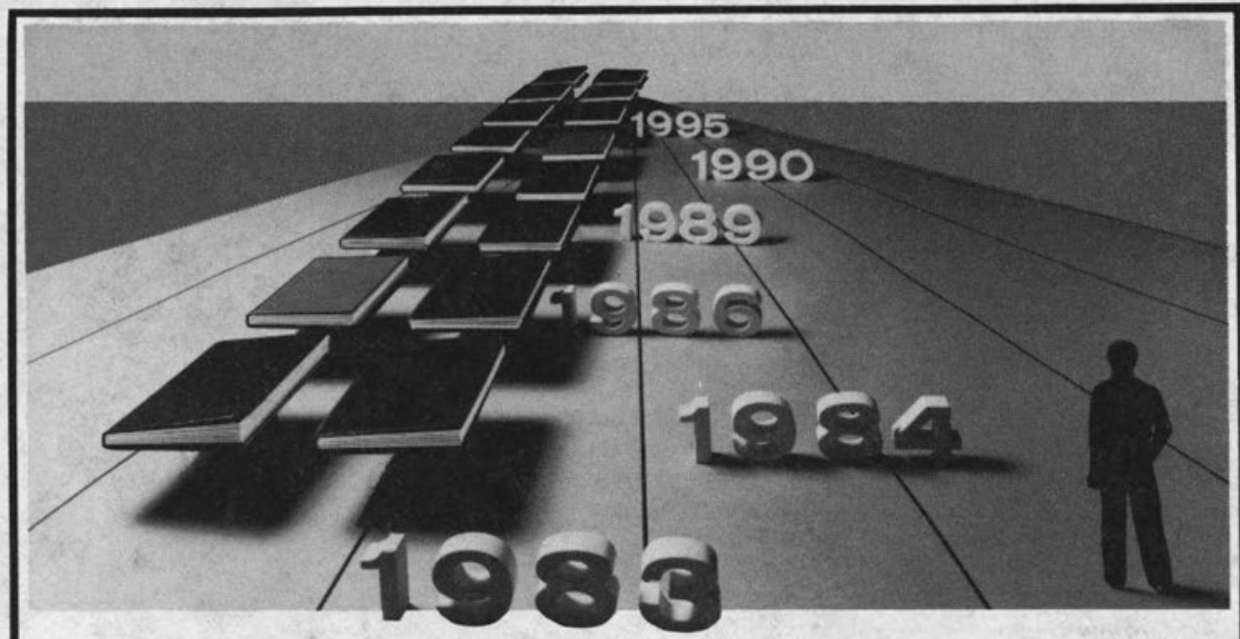

YOU'LL MANAGE

YOUR STANDING ORDERS BETTER

\section{WHEN YOU PUT THE EXPERTS TOWORK FOR YOU.}

Our Continuation Service is directed by professional librarians who offer you a full range of comprehensive selection and management tools. We never add a service charge and you can elect alternate year shipping. Discover the advantages of an automated database containing nearly 22,000 series, serials, and sets-in-progress-backed by the nation's leading supplier of books.

For details, contact the Sales Department of the division nearestyou.

EASTERN , 50 Kirby Avenue, Somerville, NJ 08876, (201) 722-8000

MIDWESTERN, 501 S. Gladiolus Street, Momence, IL 60954, (815) 472-2444

SOUTHERN, Mt. Olive Road, Commerce, GA 30599, (404) 335-5000

WESTERN , 380 Edison Way, Reno, NV 89564, (702) 786-6700 


\section{SPEED • CONTROL • FLEXIBILITY • SELECTIVITY}

\section{It's time to explore the benefits of going online with-}

\section{Books in Print}

Update monthly and more often during peak periods, the Books in Print database offers unparalleled currency and ease of access to information on some 770,000 books published or distributed in the United States. Along with in-print titles, the BIP universe includes books that will be forthcoming in the next six months and books that have been declared out-of-print or out-of-stockindefinitely since July 1979.

In addition to Author, Title, and Subject, the BIP database can be searched online by key words in a title (an extremely useful feature when only part of a title is known), subtitle, series title, pub date, LCCN, language of publication, publisher, out-of-print or active status, and additional access points which can be used alone or in combination.

Current availability: BRS and Dialog.

\section{American Men and Women of Science}

Completely update Fall 1982, the database contains biographical information on 130,500 U.S. and Canadian scientists currently active in 65 broad scientific disciplines and 800 sub-disciplines within the physical and biological sciences. In addition to accessing information by name, you can immediately identify scientists working in specific geographical locations, in specific disciplines, by educational background, earned degrees, honors and awards, personal statistics, or any combination of these and additional criteria.

Current availability: BRS. Planned availability via Dialog, March 1983.

\section{Ulrich's International Periodicals Directory (Including Irregular Serials and Annuals)}

Updated every six weeks, the UIrich's database profiles some 100,000 regularly and irregularly issued serial publications from some 65,000 publishers in 181 countries. Information on some 12,000 titles that have ceased publication since 1974 is also included. In addition to Title and Subject access, UIrich's online lets you search for serials by frequency of publication, country of publication, circulation, ISSN, Dewey Decimal number, special features (such as inclusion of advertising, book reviews, etc.) active or inactive status, and more. You can also search for titles using "key word" techniques and you can combine access points to instantly locate those publications that meet your selection criteria.

Current availability: BRS. Planned availability via Dialog, February 1983.

To subscribe through BRS (Bibliographic Retrieval Services) call (518) 783-1161 in New York State or (800) 833-4707, toll free, elsewhere. $\star$ To subscribe to Books in Print online through Dialog Information Services, call (800) 982-5838 in CA, or (800) 227-1960 elsewhere. $\star$ For additional information on online and on customized search services (U.S. \& Canada), contact Iris L. Rugoff, Business Manager, Online Services, R.R. Bowker Co., 1180 Ave. of the Americas, NY, NY 10036. Telephone: (212) 764-5107. $\star$ Outside the Western Hemisphere contact Susan Stuart, Bowker, Erasmus House, Epping, Essex, CMi16 4BU, England. Telex: 81410 